\title{
Molecular structure from models to mastery: a study of human insulin-degrading enzyme in the undergraduate biochemistry laboratory
}

Michael A. Araujo, Alexandra A. Barrere, Selena-Rae Tirado, Candace E. Williams, Monica I. Strada, and Benjamin J. Alper Sacred Heart University Department of Chemistry and Physics, 5151 Park Avenue SC105G, Fairfield, CT, 06825. alperb@sacredheart.edu

\section{Abstract}

Using crystal structure data, site directed mutagenesis, and real-time kinetic assays, students designed, expressed, and purified engineered mutants of human insulin-degrading enzyme (IDE) to explore structural requirements for enzyme function. Students demonstrated mastery of critical concepts in enzymology including principles of experimental design, implications of enzyme structure-function relationships for molecular evolution, experimental methods for analysis of macromolecular interactions, and computational approaches to scientific inquiry. This investigation was conducted as part of the second-semester undergraduate biochemistry laboratory at Sacred Heart University.

\section{Introduction}

\section{Pedagogical Approach}

Conceptual learning in inquiry-based laboratories has been shown to improve student understanding and retention [14]. The National Research Council defines inquiry-based learning as "engaging in the thinking processes and activities of a scientist [5]." Inquiry-based pedagogies exist on a continuum, where student responsibility increases from traditional laboratories to guided inquiry laboratories to open-ended inquiry and research experiences. Data from a review of NSFfunded undergraduate research programs shows that open-ended inquiry experiences increase student retention in a STEM field and indicates that students who take part in such programs are more likely to pursue a Ph.D. [6]. However, many students recognize a significant barrier for entry to such programs, as undergraduate research is typically performed outside of required coursework and performed primarily by high-achieving students benefitting from individualized extracurricular mentorship.

Accordingly, there is a recognized need to provide authentic research experiences as part of the undergraduate STEM curriculum, with the aim of increasing student retention, emphasizing critical thinking skills and lowering overall barriers to entry for advanced degrees or careers in industry [7-9]. In an instructional course-based authentic research experience, students take ownership of project design, experimentation, data collection and analysis, with the instructor serving as mentor and facilitor [10-12]. In this way, the course-based research project may serve to bridge the gap between inquiry-based laboratory work and professional scientific practice.

The reported one-semester authentic research experience presents students with an opportunity to investigate structure/function relationships in human insulin-degrading enzyme (IDE) through design and characterization of novel site-directed mutants. Aligning with key foundational objectives established by the American Society for Biochemistry and Molecular Biology (ASBMB) [13], overarching aims of this research experience were for students to apply principles of molecular evolution and protein structure and function to design and carry out a controlled study of the IDE proteolytic mechanism using molecular engineering and enzyme kinetic methods. To this end, students used threedimensional structural data and experimental techniques that included in silico modeling, evolutionary conservation analysis, molecular cloning, protein expression and purification, and real-time fluorescence resonance energy transfer (FRET) proteolytic assays to investigate the structural and mechanistic basis of IDE activity.

To structure the research experience over the course of a one semester (13 week) curricular progression, students were provided with planning and assessment scaffolds to arrange and evaluate learning outcomes (i.e., Project Checkpoints, Table 1). At the beginning of the course, essential primary literature [14], experimental techniques [15, 16] and controls for analyzing IDE proteolytic activity $[17,18]$ were discussed as foundational concepts prior to initiation of independent student research. Documentation of experimental data within an indexed, well-structured laboratory notebook served as a touchstone for interactive assessment over the course of the semester. Guidelines for formatting the lab notebook were provided (Supporting Information); however, students were granted autonomy to design their projects and implement experimental strategies without the use of a traditional laboratory manual. 


\begin{tabular}{|c|c|c|}
\hline 1 & $\begin{array}{l}\text { Literature Review: Insulin-Degrading Enzyme (IDE) } \\
\text { Laboratory Notebook Best Practices }\end{array}$ & $\begin{array}{l}\text { Group Discussion } \\
\text { Lab Notebook Rubric }\end{array}$ \\
\hline 2 & Computational Tools Activity: IDE Mutant Design & $\begin{array}{l}\text { Presentation } \\
\text { Peer/Instructor Feedback }\end{array}$ \\
\hline 3 & Laboratory prep: Luria broth, buffers, competent cells & Lab Notebook Check \\
\hline $4-5$ & $\begin{array}{l}\text { E. coli transformation with IDE plasmid expression constructs, } \\
\text { Plasmid amplification and purification }\end{array}$ & $\begin{array}{l}\text { Quiz } 1 \\
\text { Lab Notebook Check }\end{array}$ \\
\hline-10 & $\begin{array}{l}\text { Primer design using SerialCloner or SnapGene } \\
\text { Inverse PCR for IDE mutagenesis } \\
\text { In-Fusion }{ }^{\circledR} \text { gene cloning and validation } \\
\text { Recombinant IDE expression } \\
\text { Protein purification by metal affinity chromatography }\end{array}$ & $\begin{array}{l}\text { Quiz } 2 \\
\text { Lab Notebook Check }\end{array}$ \\
\hline 11 & FRET assays for real-time measurement of IDE activity & Lab Notebook Check \\
\hline-13 & $\begin{array}{l}\text { Final data collection and analysis } \\
\text { Formal Report Construction }\end{array}$ & Formal Laboratory Report \\
\hline
\end{tabular}

Table 1: Authentic Research Experience Project Outline. Student work was assessed at various points throughout the semester through peer review of the proposed experimental plan, formative laboratory notebook assessments, content based quizzes and a culminating laboratory report.

Several activities and assessments guided inquiry-based learning and provided students with timely and constructive feedback. An initial literature review was provided alongside an introduction to laboratory resources and best practices to structure potential student research objectives and methods of analysis. Next, a peer-reviewed protein primary structure, evolutionary conservation and modeling activity provided a forum to discuss structure/function enzyme mechanistic hypotheses proposed by the student. Throughout the course of the semester, laboratory notebook checks assessed student-led experimental design and execution, and provided an opportunity for the instructor to offer constructive guidance where necessary, while content-based quizzes assessed critical conceptual knowledge and student learning outcomes. A culminating laboratory report assessed students' ability to interpret experimental data as it related to their enzyme mechanistic hypotheses and provided a record of disciplinary research productivity. On course completion, an end-of-semester retrospective survey was used to monitor student perceptions of learning outcomes, technical proficiency and scientific achievement.

\section{Insulin-degrading enzyme (IDE) as a model for instructional studies of enzyme catalysis}

IDE is an attractive target for instructional study owing to broad interest in the enzyme as a potential therapeutic target, the availability of genetic and three-dimensional structural data for IDE and related homologs, and the convenience and tractability of non-hazardous real-time spectroscopic methods for analysis of IDE activity. Recombinant expression of human IDE in $E$. coli yields a soluble cytosolic protein that is readily purified in the active form and exhibits long term cold storage stability, retaining greater than $90 \%$ activity after 1 year at $-20^{\circ} \mathrm{C}$.

IDE is a large ( $110 \mathrm{kDa})$, clinically relevant zinc metallopeptidase that proteolyzes substrates including insulin19, amylin, glucagon, and atrial natriuretic peptides [20], $\beta$-amyloid [21] and others. To date, considerable work has focused on the potential roles of IDE in Type II diabetes mellitus and Alzheimer's disease [22, 23]. Structural data is available for IDE alone and in complex with multiple physiological substrates [24-27]. IDE adopts a tertiary structure that is analogous to that of a "Pac-Man" or a "clam-shell" (Figure 1). The enzyme contains a single catalytic $\mathrm{Zn}^{2+}$ ion located within the $~ 55$ $\mathrm{kDa} \mathrm{N}$-terminal subunit, while substrate binding residues of the $\mathrm{N}$ - and $\mathrm{C}$-terminal domains are required for enzyme function and also contribute to substrate specificity [16-18, 24-27]. IDE's $\mathrm{Zn}^{2+}$ ion is coordinated by residues of the $H x x E H$ metalloprotease motif, which is invariant among M16 family peptidases. In this motif, absolutely conserved histidine and glutamate residues are essential for zinc binding and catalysis by IDE and its homologs $[17,18,28]$. 
A.

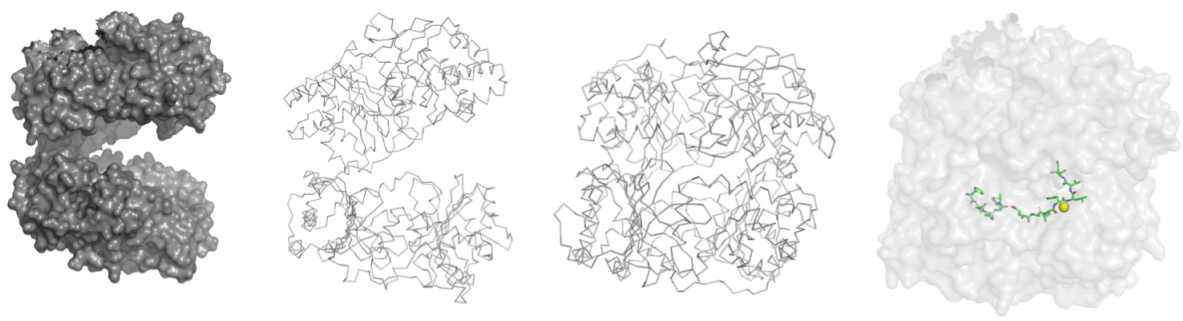

B.

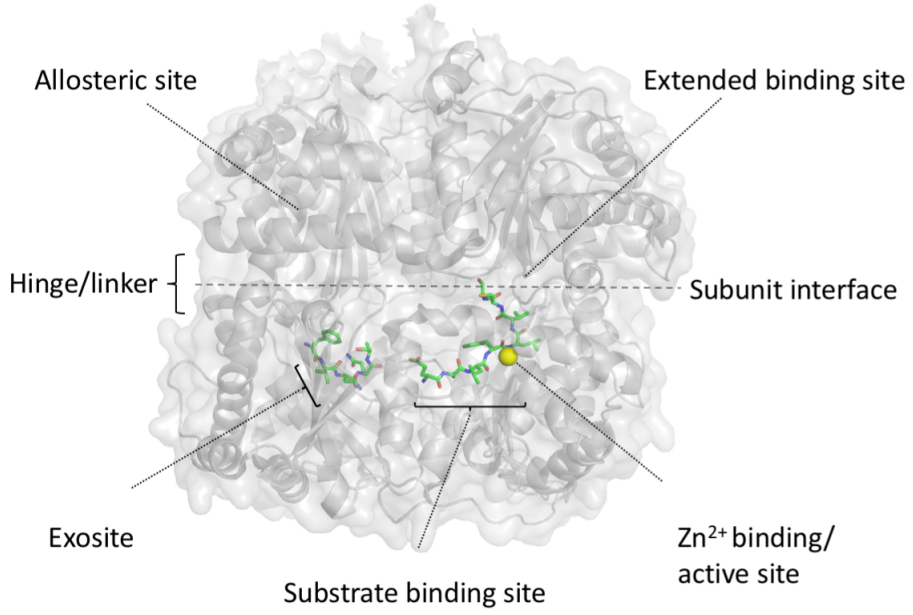

C.

\begin{tabular}{|c|c|}
\hline Mutagenic target & Region \\
\hline F115 & Substrate binding site \\
\hline N125 & Substrate binding site \\
\hline S137 & Substrate binding site \\
\hline N139 & Substrate binding site \\
\hline F141 & Substrate binding site \\
\hline T142 & Substrate binding site \\
\hline E182 & Substrate binding site \\
\hline W199 & Substrate binding site \\
\hline T220 & Substrate binding site \\
\hline E189 & Active site \\
\hline
\end{tabular}

\begin{tabular}{|c|c|}
\hline Mutagenic target & Region \\
\hline D426 & Subunit interface \\
\hline R429 & Allosteric site \\
\hline N528 & Hinge/linker \\
\hline K571 & Subunit interface \\
\hline Y609 & Exosite \\
\hline E817 & Subunit interface \\
\hline T825 & Extended binding site \\
\hline E827 & Extended binding site \\
\hline Q828 & Extended binding site \\
\hline V833 & Extended binding site \\
\hline
\end{tabular}

Figure 1: Structural perspectives of human insulin degrading enzyme (IDE) alone and in complex with peptide substrate. A. "Open" structure of substrate-free IDE (PDB 6B7Y [26]) and "closed" structure of IDE in complex with AB 1-42 peptide (PDB 2WK3 [27]). B. Established and prospective structural features of IDE are shown. C. Student-designed IDE mutants targeting structural motifs of IDE with recognized or yet-to-be characterized mechanistic functions were characterized over the course of the authentic research experience.

Enzyme engineering approaches (i.e., IDE mutants) previously used to characterize IDE function are well annotated in the BRENDA enzymes database [29]. Importantly, IDE contains several less well-characterized structural features and motifs, which present intriguing targets for continuing enzyme mechanistic studies. These features include extended substrate binding interfaces of the IDE active and exosites, $\mathrm{N}$ - and $\mathrm{C}$-terminal subunit oligomerization interfaces, sites for interaction of allosteric modulators, and conserved enzymatic motifs that have yet to be investigated. Structural and functional requirements in these and other conserved regions of IDE were characterized by student researchers over the course of the research experience. 


\section{Materials and methods}

\section{Course structure and resources}

The reported investigation was conducted as part of the second-semester undergraduate biochemistry curriculum (Biochemistry II, CH342) at Sacred Heart University (Fairfield, CT). This course explores concepts in biological signaling, bioenergetics, metabolism, genome structure and gene expression. Students of this course have completed the first semester biochemistry curriculum, which treats on the structures and functions of various classes of biomolecules and introduces enzyme kinetic models, molecular biology tools and in silico modeling resources

The second semester biochemistry curriculum is made up of co-administered laboratory and lecture sections. The course meets once weekly for a 3 hour lab period and twice weekly for 1 hour and 15 minute lecture periods. The curriculum served 14 students in Spring 2018, and is offered on a yearly basis. The curriculum is administered in a "labture" modality with overlapping projects and discussion in both the classroom and laboratory. The research project is initiated in the classroom with a literature review and assignment of a computational modeling acticity, then transitions into the laboratory for experimental construction and characterization of IDE mutants. The biochemistry laboratory at Sacred Heart University is equipped with a multimode UV/Vis-plate reader (BioTek Synergy HT; BioTek USA, Winooski, VT), PCR thermal cycler, autoclave, cell culture incubators, incubator/orbital shakers, probe-sonicator, bench-top and microcentrifuges, as well as standard equipment for gel electrophoresis and solution preparation and handling, with access to $-20^{\circ} \mathrm{C}$ and $-80^{\circ} \mathrm{C}$ freezers for biological materials storage. There is bench space in the lab for up to 12 students, with sufficient resources to support students to working in groups or independently.

The overall project workflow is summarized in Figure 2. Following introduction of course learning objectives as part of a discussion-based literature review, students are provided with primary sequence information for IDE and related M16A homologs and PDB structural coordinates for IDE in complex with insulin and amyloid-beta peptides (PDB 2 G47 and PDB $2 \mathrm{G} 54[25])$.

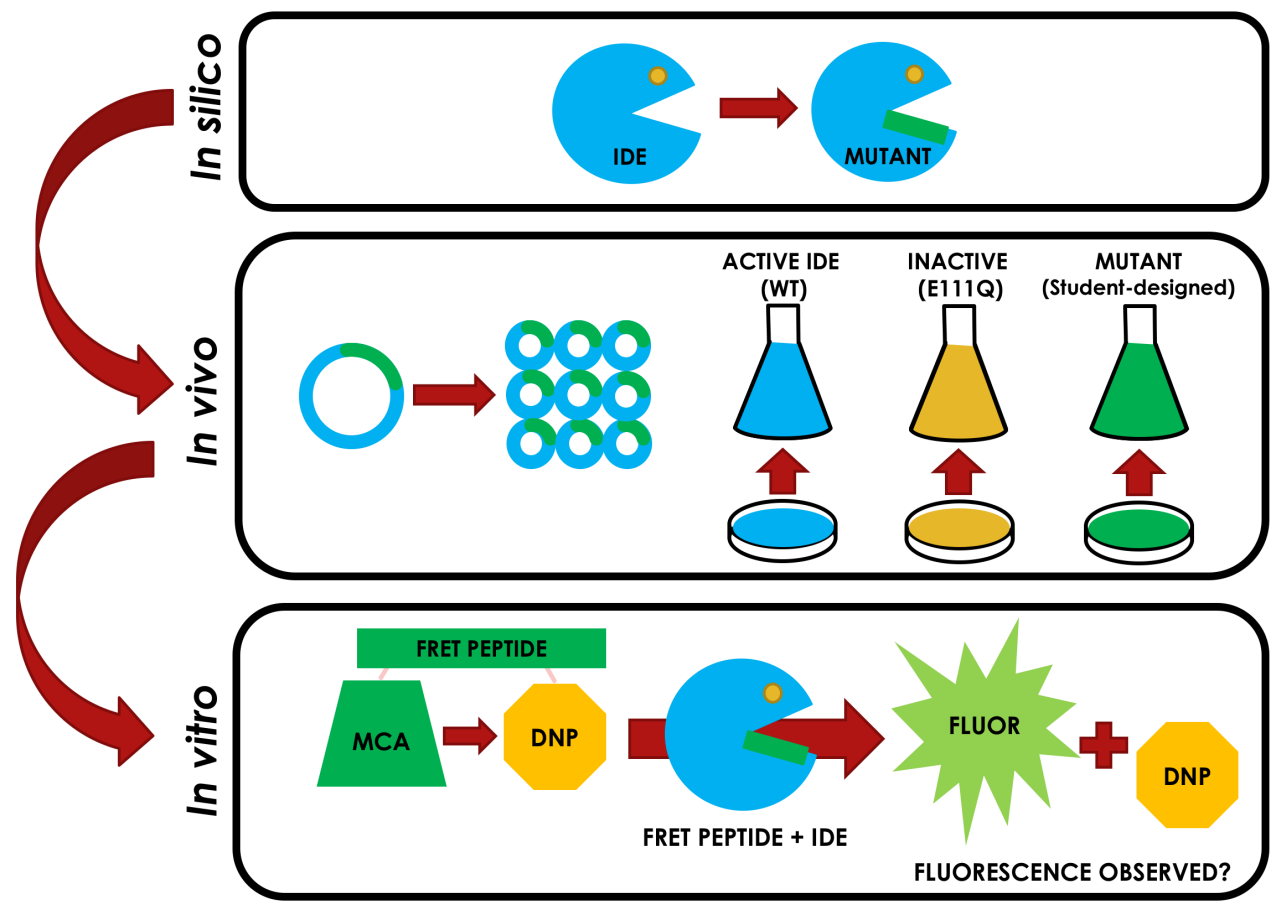

Figure 2. Project workflow. Students used primary and tertiary and structure characteristics of human IDE and its homologs to design an IDE mutant affording potential mechanistic insight in silico. IDE mutants were in turn generated by inverse PCR using mutagenic primers and validated by Sanger sequencing. Confirmed clones were expressed in the bacterial host in vivo, and purified by immobilized metal affinity chromatography. Kinetic parameters of proteolytic function for student-designed IDE mutants were evaluated in vitro using real-time high-throughput fluorescence resonance energy transfer (FRET) assays. 
Students designed IDE mutants on the basis of protein primary and tertiary structure, and were directed to confirm the novelty of their proposed substitution by survey of the PubMed and BRENDA databases. Building from an initial primary sequence analysis, in which students prepare a multisequence alignment using bacterial, yeast, mammalian IDE homologs with Clustal $\omega$ [30-32], students were tasked with identifying a region or residue of IDE that could be targeted using engineering approaches to develop or advance novel or existing structure-function hypotheses informing IDE enzymatic mechanism.

\section{Computational tools for protein structure modeling}

Student-led structural investigations were introduced in the context of a guided discussion of computational methods used to conduct enzyme structure/function analyses (I.e., the Computational Tools Activity, see Supporting Information). First, students were tasked with identifying evolutionary conserved regions of IDE using the Clustal $\omega$ multiple sequence alignment software [30-32]. Students compared primary structures of multiple IDE homologs (Homo sapiens IDE, GenBank accession no. AAA52712; Rattus norvegicus IDE, NCBI reference sequence accession no. NP_037291; Saccharomyces cerevisiae Ste23p, NCBI reference sequence NP_013493; Eschericia coli pitrilysin, WP_105906370), revealing regions of evolutionary homology.

A.
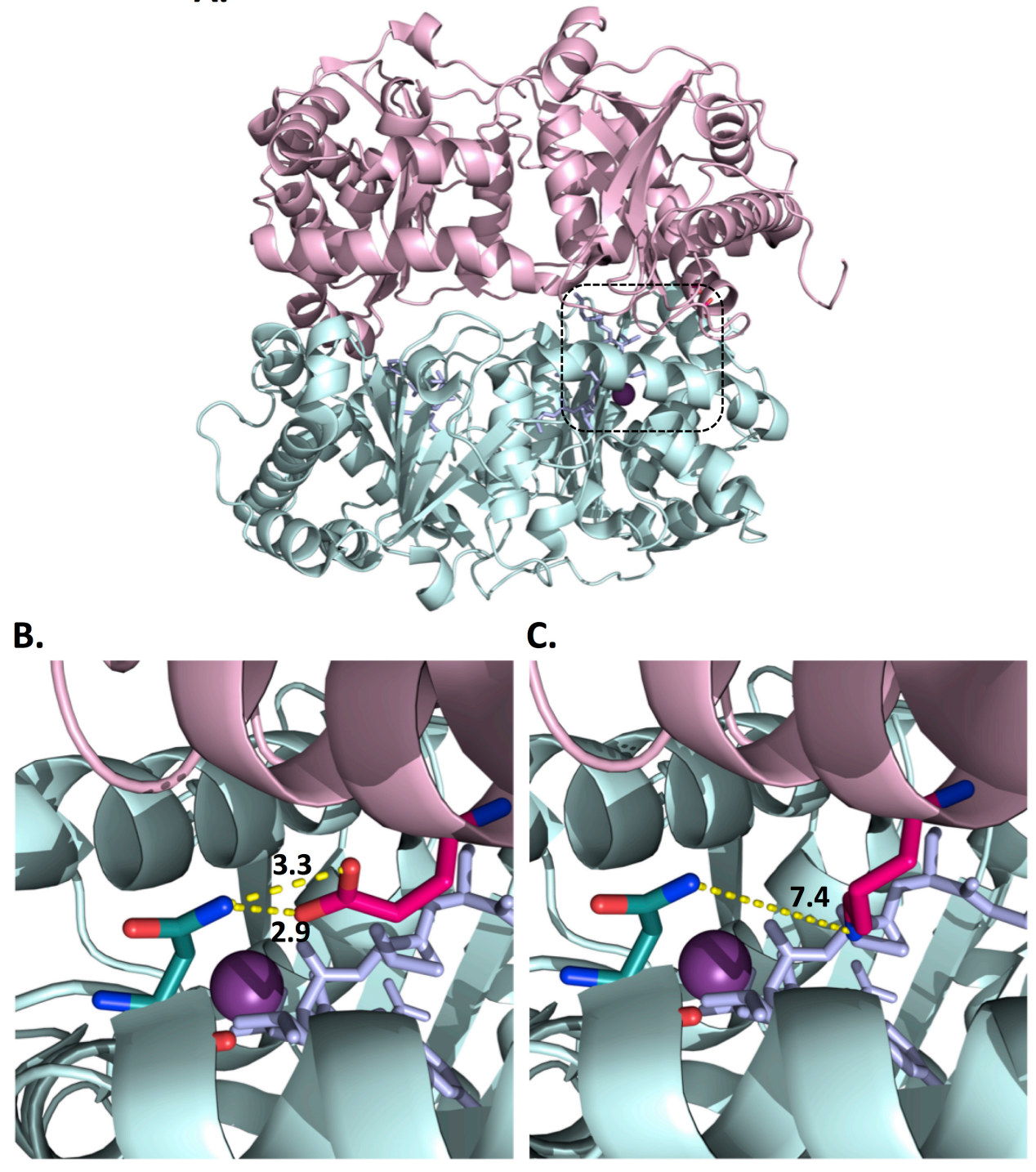

Figure 3: PyMOL representation of insulin-degrading enzyme (IDE) in complex with substrate. A. Representation of IDE in complex with insulin (PDB 2G54, [14]). IDE-N and IDE-C terminal domains are colored pale cyan and light pink, respectively. IDE esidue E817, bound $\mathrm{Zn}{ }^{2+}$, and substrate are colored hot pink, purple, and light blue, respectively. B. Close-up of the WT IDE of "latch-site". The E817 (hot pink)/N125 (teal) interaction is predicted to be important to catalytic function. C. Model of the IDE E817K mutant. The E817K (hot pink) substitution is predicted to disrupt the latch mechanism of IDE, affecting catalytic activity. The models in this figure were prepared by C. Williams using PyMOL [33]. 
Next, students examined the three-dimensional structures of human IDE in complex with insulin (PDB 2G54) or amyloidbeta peptides (PDB 2G47) using the PyMOL molecular structure visualization tool [33], framing proposal and modeling of a student-designed IDE mutation, which was appraised for novelty by comparison with previously reported IDE mutants curated in BRENDA. Once a proposed mutant was identified by the student, the proposed mutation and experimental approach for assessing impact on IDE function were subject to peer review through an oral presentation and discussion. Here, students were encouraged to consider and develop experimental rationale, controls, and proposed approaches for their proposed mechanistic hypothesis. IDE mutants were in turn recombinantly expressed in $E$. coli, purified by immobilized metal affinity chromatography, and characterized using proteolytic assays reported previously $[15,16]$ and described below.

\section{Molecular cloning and construction of IDE mutants}

Student construction of IDE site-directed mutants was achieved through inverse PCR with mutagenic oligonucleotides in conjunction with the In-Fusion ${ }^{\circledR}$ molecular cloning system [34] (Takara Bio USA Inc., Mountain View CA). PCR products were generated through site directed mutagenesis of an IDE gene that directed expression of the C-terminal polyhistidine tagged fusion protein (described in [16]).

A.

Yeast IHEPCFDTLRTKE 836

Rat ISEPCFNTLRTKE 827

Human ISEPCFNTLRTKE 827

E817K ISKRPCFNTLRTKE 827

C.

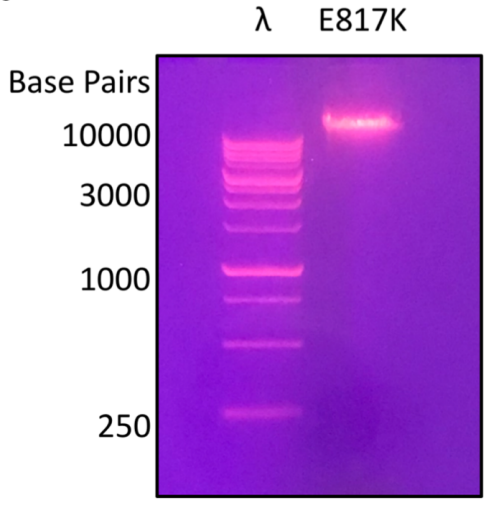

B.

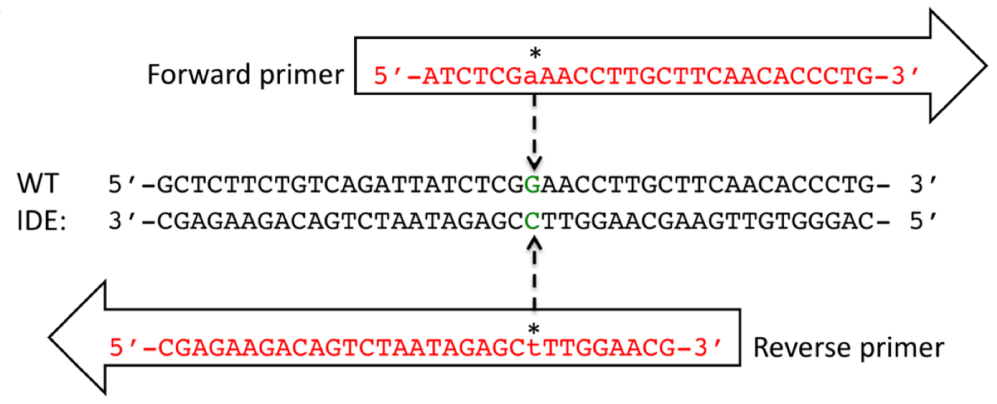

D.

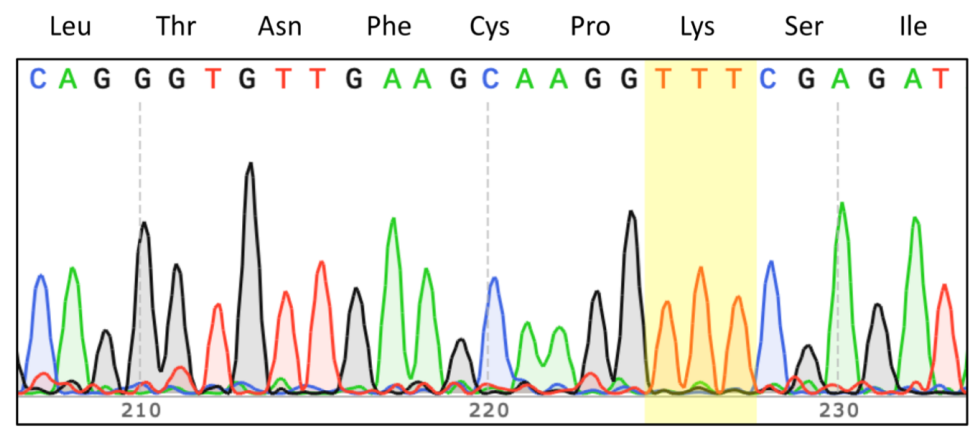

Figure 4: Construction and validation of the IDE E817K mutant. A. Multiple sequence alignment of yeast, rat, and human IDE homologs with the E817K mutant. Position 817 is underlined and noted with an asterisk. B. E817K primer design for site-directed mutagenesis by inverse PCR. Mutagenic oligos are colored red. IDE cDNA is colored black, with native sequence targeted for mutagenesis colored green. C. Agarose gel electrophoresis of inverse PCR product later circularized using the In Fusion cloning system (Takara Bio USA). Lane 1: DNA size standard, Lane 2: E817K mutant. D. Sanger sequencing of the E817K mutagenic site complementary strand (Yale Keck DNA sequencing Facility). The AAA (TTT) codon directing expression of lysine at residue 817 is highlighted in yellow. Models and data analysis in this figure were prepared by S. Tirado. 
Students applied established methods for expression and purification of polyhistidine tagged IDE. These methods have been described previously [16], and were carried out with significant instructor oversight. Bacterial cells were cultured to high density $\left(>0.5 \mathrm{OD}_{600}\right)$ under antibiotic selection in lysogeny broth supplemented with $50 \mathrm{\mu g} / \mathrm{mL}$ kanamycin prior to overnight induction of protein expression on addition of $0.1 \mu \mathrm{M}$ IPTG to $100 \mathrm{~mL}$ bacterial culture medium. Following protein expression, cells were harvested by centrifugation using a refrigerated centrifuge $\left(3,500 \mathrm{~g} \times 15 \mathrm{~min} ., 4^{\circ} \mathrm{C}\right)$ and residual culture medium was removed by rinsing with phosphate buffered saline $(137 \mathrm{mM} \mathrm{NaCl}, 2.7 \mathrm{mM} \mathrm{KCl}, 10 \mathrm{mM}$ $\mathrm{NaH}_{2} \mathrm{PO}_{4}, 1.8 \mathrm{mM} \mathrm{KH}_{2} \mathrm{PO}_{4}$ ).

Cell lysis was achieved by ultrasonic disruption (VirTis VirSonic ultrasonic cell disruptor 100 probe sonicator). Two 30 second pulses were performed at intensity setting 5 with intermittent icing between samples, and lysates were clarified by centrifugation to remove insoluble material $\left(3500 \mathrm{~g} \times 15 \mathrm{~min}, 4^{\circ} \mathrm{C}\right)$. The clarified supernatant was further purified by gravity flow immobilized metal affinity chromatography using $1 \mathrm{~mL}$ bed volume nickel-IDA resin with initial loading and 3 rinses performed using $10 \mathrm{~mL}$ lysis/wash buffer comprising $300 \mathrm{mM} \mathrm{NaCl}, 20 \mathrm{mM}$ imidazole, $50 \mathrm{mM}$ sodium phosphate $\mathrm{pH}$ 7.4, and elution with $1 \mathrm{~mL} 300 \mathrm{mM} \mathrm{NaCl} 300 \mathrm{mM}$ imidazole $50 \mathrm{mM}$ sodium phosphate, $\mathrm{pH}$ 7.4. All buffers were prepared by students early in the experimental workflow. Protein concentration was determined relative to BSA standards using a modified version of the Bradford Assay [35]. Purified proteins were supplemented with $50 \%$ glycerol and stored at $-20^{\circ} \mathrm{C}$ until they were subject to characterization by SDS-PAGEwith Coomassie Brilliant Blue Staining [36] and enzyme kinetic assay.

\section{Kinetic assays for IDE proteolytic activity}

Several real-time fluorogenic assays for the characterization of IDE activity permit high-throughput kinetic characterization of IDE activity. FRET substrates based on IDE substrates enkephalin, insulin, and amyloid beta were used as dictated by the student-developed hypothesis $[15,16]$. Each of the available FRET substrates contains a fluorogenic methylcoumaric acid (MCA) moiety that within the intact peptide is positioned in close proximity to quenching group (dinitrophenol; DNP). Upon proteolytic cleavage by IDE, the fluorescing and quenching moieties are free to diffuse in solution, limiting their spatial proximity and resulting in increased overall sample fluorescence that can be measured in real time (Figures 2 and 5).

\section{Results}

Students generated multiple IDE mutants over the course of each semester Most IDE mutants were stably expressed and could be isolated as proteins of the expected molecular mass that were purified to near homogeneity. Typical yields were between 0.1 and $0.5 \mathrm{mg}$ of $>90 \%$ purified enzyme, as assessed by Bradford Assay and SDS-PAGE. Of the purified IDE mutants, a majority were observed to impact enzyme activity, and therefore held to be potentially important for enzyme function.

Several regions of IDE structure emerged as common targets for student-led investigations. For example, several students investigated functional requirements for conservation of hydrophobic residues of the enzyme active site in substrate binding, recognition and proteolysis. Additionally, electrostatic requirements for putative charge-sharing residues of IDE $\mathrm{N}$ - and $\mathrm{C}$ - terminal subunit interfaces, including prospective functional requirements for conserved amino acid motifs at the interface of IDE N- and C- terminal "clam-shell" domains, and requirements for conservation of allosteric site residues were also investigated.

Further characterization of mutants by researchers taking part in the second semester biochemistry laboratory frequently served as a topic for continuing study that extended beyond the scope of the semester-long instructional curriculum. Interested students were encouraged to continue to refine and develop their work in partial fulfillment of an independent research credit ( $\mathrm{CH} 395$ - Undergraduate Research Project), which serves as a requirement for the undergraduate chemistry and biochemistry degree programs. 
A.

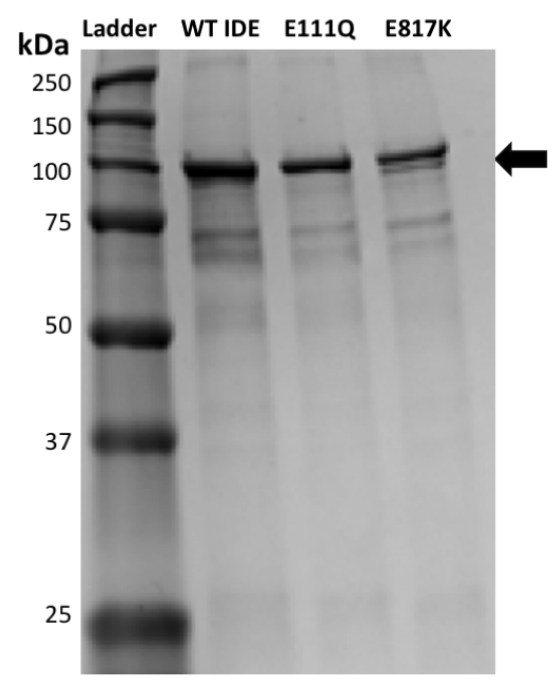

B.

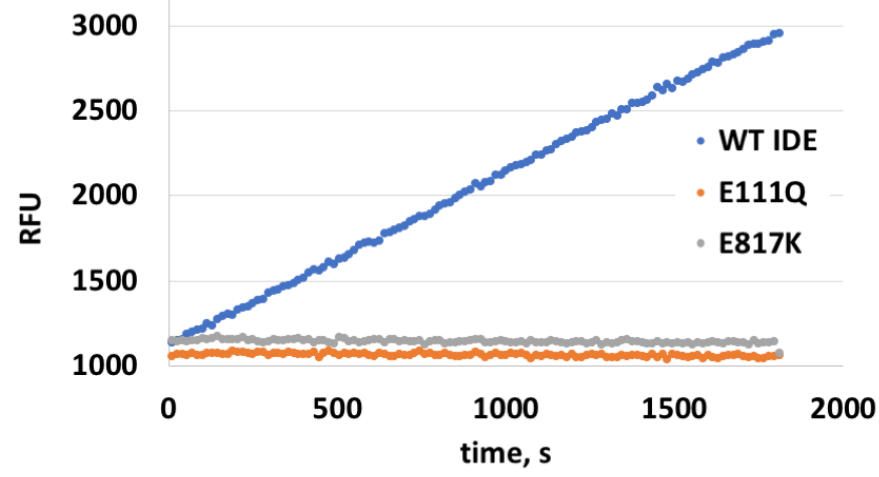

C.

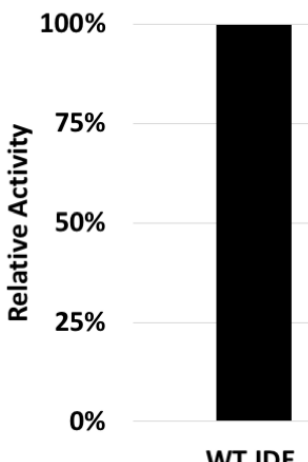

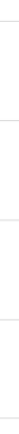

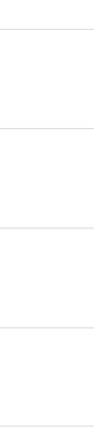

E111Q

E817K

Figure 5: Purification and kinetic analysis of IDE and mutant derivatives. A. Purified wild-type IDE (WT IDE), a catalytically inactive IDE viariant (E111Q), and a student-designed site-directed IDE mutant (E817K) were expressed in E. coli strain BL21 DE3, purified by immobilized nickel affinity chromatography, and characterized by SDS-PAGE. A Coomassie Brilliant Blue stained polyacrylamide gel with $3 \mu \mathrm{g}$ protein input perlane is shown. The predicted mass of IDE and derivative mutants is $110 \mathrm{kDa}$ (arrow). B. Reaction progress curve from FRET assay investigating IDE-mediated cleavage of fluorogenic substrate V (Mca-RPPGFSAFK-Dnp; R\&D systems). RFU: relative fluorescence units. C. Relative activity of IDE and derivative mutants. The IDE E817K mutant did not exhibit detectable substrate proteolysis. Data and analysis in this figure by M. Araujo.

\section{Assessment}

Learning outcomes were evaluated throughout the semester using methods including written and oral presentations, laboratory notebook checks, and lab quizzes. Collectively, these tools permitted assessment of students' knowledge of structure/function relationships, molecular evolution, mechanisms of enzyme function, proficiency in application of computational tools and principles of experimental design, and students' ability to conduct and analyze results from hypothesis driven research. Most sudents demonstrated proficiency in application of PyMOL and Clustal $\omega$, and designed mutants that were supported by structural rationale. In many cases, instructor and peer feedback allowed students' whose hypotheses were poorly supported by methods available for application in the research laboratory to review and restructure their work in the context of a more tractable experimental plan.

Laboratory notebook checks encouraged students to maintain proficient records, and provided an opportunity for regular feedback and instructor input. Quizzes assessed and encouraged content knowledge regarding critical experimental theory, and a cumulative lab report permitted evaluation of skills-based achievement and analysis of project outcomes. A rubric for the comprehensive report structured assessment of students' ability to collect and synthesize experiemental data and to formulate reasonable conclusions in the context of experimental data and the scientific literature. Importantly, students who failed to generate experimental data in support of a particular structural hypothesis did not result in a low grade, but rather, like all other students, were evaluated on the quality of their record keeping, conceptual knowledge, and reflective assessment and account of their research. Student engagement was assessed on the basis of regular and timely attendance, performance and professionalism, incentivizing participation and achievement. 
An exit survey assessed student perceptions of success of the research curriculum (Table 2). The overwhelming majority of students strongly agreed that the course helped deepen their understandings of structure/function relationships and computational tools. Student confidence and skills in the laboratory grew as a result of their project and the majority preferred to be in a course where they were in charge of the experimental design. Peer and instructor feedback as part of the learning loop was deemed valuable to learning outcomes. On the whole, the authentic research experience was favorably received, and succeeded in its primary goals of facilitating student mastery of technical skills, conceptual understanding, and confidence in inquiry-based problem and hypothesis driven research.

\begin{tabular}{|c|c|}
\hline Question & $\begin{array}{l}\text { Average Response } \\
\text { (std. dev.) }\end{array}$ \\
\hline $\begin{array}{l}\text { Primary literature discussions were helpful for } \\
\text { informing my hypothesis of a viable IDE mutant }\end{array}$ & $4.7(0.5)$ \\
\hline $\begin{array}{l}\text { The computational tools project furthered my } \\
\text { understanding of IDE structure and mutant } \\
\text { design }\end{array}$ & $4.7(0.5)$ \\
\hline $\begin{array}{l}\text { My experiences with using computational tools } \\
\text { in this laboratory will of use in my future } \\
\text { courses and/or graduate work }\end{array}$ & $4.4(0.7)$ \\
\hline $\begin{array}{l}\text { Peer and instructor feedback on IDE mutant } \\
\text { design was valuable for this project }\end{array}$ & $4.9(0.3)$ \\
\hline $\begin{array}{l}\text { Developing a cloning strategy helped further } \\
\text { my understandings of DNA technology }\end{array}$ & $4.8(0.4)$ \\
\hline $\begin{array}{l}\text { I was able to use prior skills and knowledge } \\
\text { from biochemistry or molecular biology courses } \\
\text { to design my experiments for this project }\end{array}$ & $4.8(0.7)$ \\
\hline $\begin{array}{l}\text { I prefer a laboratory course where I have the } \\
\text { opportunity to design experiments }\end{array}$ & $4.4(0.9)$ \\
\hline $\begin{array}{l}\text { My confidence in my ability to learn new and } \\
\text { difficult material grew as a result of this course }\end{array}$ & $4.6(0.5)$ \\
\hline $\begin{array}{l}\text { My problem-solving and laboratory skills } \\
\text { increased as a result of this course }\end{array}$ & $4.7(0.5)$ \\
\hline $\begin{array}{l}\text { I successfully kept a thorough laboratory } \\
\text { notebook for the duration this course }\end{array}$ & $4.6(0.5)$ \\
\hline
\end{tabular}

Table 2: Exit survey of students from the $\mathbf{2 0 1 8}$ spring semester (13 of 14 students responding). Likert scale average responses ranging from $5=$ strongly agree to $1=$ strongly disagree and standard deviation among responses are shown.

\section{Discussion}

This activity succeeded in introducing and reinforcing concepts in molecular evolution, enzyme structure, function and kinetic models, and in engaging undergraduate students in primary research. Student perceptions of the reported activity were generally favorable, as noted in student responses to the retrospective survey and course evaluations. Several students elected to continue pursue work related to this study as independent "capstone" research. In addition, several students reported pre-health professional interviews (pre-med, pre-dent, pre-pharm) favorably relating the reported research experience, and several students of the course have pursued scientific professions including masters and doctoral studies in the molecular life sciences. Current and future goals for the educational research program include publication of student research in peer reviewed scientific journals and continued student development as molecular life scientists, medical researchers and health practitioners. Student identification of residues critical to IDE function in the reported research experience may also inform the development of non-hydrolyzable insulin analogs or design of IDE inhibitors as part of an interdisciplinary training environment. 


\section{Acknowledgements}

We are grateful to the Department of Chemistry and Physics, and the College of Arts and Sciences at Sacred Heart University for supporting this work, and to Dr. Walter K. Schmidt Jr. (University of Georgia) for the IDE expression construct). We are thankful also to the many students who took part in this laboratory over several years of course administration who are not recognized with authorship here.

\section{Supporting Information}

Instructional materials including the laboratory syllabus, supporting protocols, project handouts, assessment rubrics, quizzes, and instructor notes for lab safety are provided in the Supporting Information.

\section{References}

1. Bain, K. (2004) What the Best College Teachers Do. Harvard University Press, Cambridge.

2. Knutson (2010) Bringing Excitement and Motivation of Research to Students; Using Inquiry and Research-Based Learning in a Year-Long Biochemistry Laboratory. Biochem Mol Biol Educ. 38, 317-323

3. Lord, T. and Orkwiszewski, T. (2006) Moving from didactic to inquiry based instruction in a science laboratory. Am Biol Teach. 63, 342-345

4. National Research Council Committee on Undergraduate Science Education (1999) Transforming Undergraduate Education in Science, Mathematics, Engineering, and Technology. The National Academies Press, Washington, D.C.

5. Weaver (2008) Inquiry-based and research-based laboratory pedagogies in undergraduate science. Nat Chem Bio. 4, 577-80

6. Russell, S.H. (2006) Evaluation of NSF support for undergraduate research opportunities. SRI International <http://www.sri.com/policy/csted/reports/university/documents/UROSynthesis for Web Jul 5 06.pdf>.

7. Nagda, B.A.; Gregerman, S.R.; Jonides, J.; von Hippel, W.; Lerner, J.S. (1998) Undergraduate student-faculty partnerships affect student retention. Rev. Higher Educ. 22, 55-72.

8. National Research Council. 2003. Improving Undergraduate Instruction in Science, Technology, Engineering, and Mathematics: Report of a Workshop. Washington, DC: The National Academies Press.

https://doi.org/10.17226/10711.

9. Caspers, M. L. and Roberts-Kirchhoff, E. S. (2006) An undergraduate biochemistry laboratory course with an emphasis on a research experience. Biochem Mol Biol Educ. 31, 303-307.

10. Gray, C., Price, C. W., Lee, C. T., Dewald, A. H., Cline, M. A., McAnany, C. E., Columbus, L. and Mura, C. (2015), Known structure, unknown function: An inquiry-based undergraduate biochemistry laboratory course. Biochem Mol Biol Educ. 43, 245-262.

11. Muth, G. W. and Chihade, J. W. (2008), A streamlined molecular biology module for undergraduate biochemistry labs. Biochem Mol Biol Educ. 36, 209-216.

12. Weaver G. C., Wink D., Varma-Nelson P., Lytle F., Morris R., Fornes W., et al. (2006), Developing a new model to provide first and second-year undergraduates with chemistry research experience: Early findings of the Center for Authentic Science Practice in Education (CASPiE). Chemical Educator. 11, 125-129.

13. White, H. B., Benore, M. A., Sumter, T. F., Caldwell, B. D. and Bell, E. (2013), What skills should students of undergraduate biochemistry and molecular biology programs have upon graduation? Biochem Mol Biol Educ. 41, 297-301.

14. Shen, Y., Joachimiak, A., Rosner, M. R., Tang, W.J. (2006) Structures of human insulin-degrading enzyme reveal a new substrate recognition mechanism. Nature. 443, 870-874.

15. Johnson G.D., Ahn K. (2000) Development of an internally quenched fluorescent substrate selective for endothelin-converting enzyme-1. Anal Biochem. 286, 112-8.

16. Stefanidis, L., Fusco, N.D., Cooper, S.E., Smith-Carpenter, J.E., Alper, B.J. (2018) Molecular determinants of substrate specificity in human insulin-degrading enzyme. Biochemistry. 57, 4903-4914.

17. Perlman, R. K.; Gehm, B. D.; Kuo, W. L.; Rosner, M. R. (1993) Functional analysis of conserved residues in the active site of insulin-degrading enzyme. J Biol Chem. 268, 21538-21544. 
18. Perlman, R. K.; Rosner, M. R. (1994) Identification of zinc ligands of the insulin-degrading enzyme. J Biol Chem. 269, 33140-33145.

19. Mirsky, I. A. and Broh-Kahn, R. H. (1949) The inactivation of insulin by tissue extracts. I. The distribution and properties of insulin inactivating extracts insulinase. Arch Biochem. 20, 1-9.

20. Bennett, R.G., Duckworth, W.C., Hamel F.G. (2000) Degradation of Amylin by Insulin-degrading Enzyme. J Biol Chem 275, 36621-36625

21. Farris, W.; Mansourian, S.; Chang, Y.; Lindsley, L.; Eckman, E. A.; Frosch, M. P.; Eckman, C. B.; Tanzi, R. E.; Selkoe, D. J.; Guennette, S. (2003) Insulin-degrading enzyme regulates the levels of insulin, amyloid $\beta$-protein, and the $\beta$ amyloid precursor protein intracellular domain in vivo. Proc Nat Acad Sci. 100, 4126-4167.

22. Duckworth, W.C.; Bennett, R. G.; Hamel, F.G. (1998) Insulin Degradation: progress and potential. Endocrine Rev. 5, 608-624.

23. Kurochkin, I. V.; Guarnera, E.; Berezovsky, I. N. (2018) Insulin-Degrading Enzyme in the Fight against Alzheimer's Disease. Trends Pharmacol. Sci. 39, 49-58.

24. Im, H.; Manolopoulou, M.; Malito, E.; Shen, Y.; Zhao, J.; Neant-Fery, M.; Sun, C. Y.; Meredith, S. C.; Sisodia, S. S.; Leissring, M. A.; Tang, W. J. (2007) Structure of substrate-free human insulin-degrading enzyme IDE, and biophysical analysis of ATP-induced conformational switch of IDE. J. Biol. Chem. 282, 25453-25463.

25. Shen, Y.; Joachimiak, A.; Rosner, M. R., Tang, W. J. (2006) Structures of human insulin-degrading enzyme reveal a new substrate recognition mechanism. Nature 443, 870-874.

26. Zhang, Z.; Liang, W. G.; Bailey, L. J.; Tan, Y. Z.; Wei, H.; Wang, A.; Farcasanu, M.; Woods, V. A.;McCord, L. A.; Lee, D.; Shang, W.; Deprez-Poulain, R.; Deprez, B.; Liu, D. R.; Koide, A.; Koide, S.; Kossiakoff, A. A.; Li, S.; Carragher, B.; Potter, C. S.; Tang, W. J. (2018) Ensemble cryoEM elucidates the mechanism of insulin capture and degradation by human insulin degrading enzyme. eLife. 7, e33572.

27. Guo Q, Manolopoulou M, Bian Y, Schilling AB, Tang WJ. Molecular basis for the recognition and cleavages of IGF-II, TGF-alpha, and amylin by human insulin-degrading enzyme. (2010) J. Mol. Biol. 395, 430-443

28. Becker, A. B.; Roth, R. A. (1992) An unusual active site identified in a family of zinc metalloendopeptidases. Proc. Natl. Acad. Sci. USA. 89, 3835-3839.

29. Schomburg, I., Hofmann, O., Baensch, C., Chang, A., Schomburg, D., Enzyme data and metabolic information: BRENDA, a resource for research in biology, biochemistry, and medicine. (2000) Gene Funct. Dis. 3-4, 109-18. BRENDA is available at www.brenda-enzymes.org

30. Sievers F, Wilm A, Dineen D, Gibson TJ, Karplus K, Li W, Lopez R, McWilliam H, Remmert M, Söding J, Thompson JD, Higgins DG (2011) Fast, scalable generation of high-quality protein multiple sequence alignmentsusing Clustal Omega. Mol Syst Biol 7:539.

31. McWilliam H, Li W, Uludag M, Squizzato S, Park YM, Buso N, Cowley AP, Lopez R (2013) Analysis Tool Web Services from the EMBL-EBI. Nucleic Acids Res 41(W):W597-600.

32. Li W, Cowley A, Uludag M, Gur T, McWilliam H, Squizzato S, Park YM, Buso N, Lopez R (2015) The EMBL-EBI bioinformatics web and programmatic tools framework. Nucleic Acids Res 43(W1):W580-4

33. PyMOL The PyMOL Molecular Graphics System, Version 2.0 Schrödinger, LLC.

34. Berrow, N.S., Alderton, D., Sainsbury, S., Nettleship, J., Assenberg, R., Rahman, N., Stuart, D.I., Owens, R.J. A versatile ligation-independent cloning method suitable for high-throughput expression screening applications. (2007) Nucleic Acids Res. 35:e45.

35. Bradford, M.M. (1976) A rapid and sensitive method for the quantitation of microgram quantities of protein utilizing the principle of protein-dye binding. Anal Biochem. 72, 248-254.

36. Candiano, G.; Bruschi, M.; Musante, L.; Santucci, L.; Ghiggeri, G.M.; Carnemolla, B.; Orecchia, P.; Zardi, L.; Righetti, P.G. (2004) Blue silver: a very sensitive colloidal Coomassie G-250 staining for proteome analysis. Electrophoresis., $25,1327-1333$. 